\title{
Fodder productivity of Lucerne-grass mixture depending on fertilizer system and methods of presowing treatment of seeds of leguminous ingredient
}

\begin{abstract}
Senyk I.
Ternopol state agricultural experimental station of the Institute of fodder crops and agriculture of Podillia of NAAS, Trolleibusna Str., 12, Ternopil, 46400,Ukraine; e-mail: senyk_ir@ukr.net

The purpose. To study influence of presowing treatment of seeds of leguminous ingredient and fertilizer system on fodder productivity of Lucerne-cereal grass mixture. Methods. General scientific and special: field, laboratory, design, mathematical-statistical. Researches were spent by laboratory of fodder production and agroecology of Ternopil experimental station of Institute of veterinary medicine of NAAS on dark grey podzolized soils with average loamy mechanical grading. Scheme of experience included 3 factors: factor A treatment of seeds, factor B - doses of fertilizers, factor $\mathrm{C}$ - foliar top dressing. The grass mixture consisted of Medicago sativa L. of grade Siniukha, Bromus inermis Leus. of grade Mars, Festuca arundinaceae Schreb. of grade Lyudmila. It was formed in view of results of researches of scientists of Institute of fodder crops and agriculture of Podillia of NAAS. Foliar top dressing with Triamin Plus was made in the beginning of aftergrowing of each hay cutting (BBCH 31 for Lucerne and $\mathrm{BBCH}$ 21-22 for cereal grasses) at presence of sufficient leaf area in dose of $2 \mathrm{l} /$ hectare and charge of working solution of $250 \mathrm{l} /$ hectare. Mowing of grass mixture was carried out at approach of maturity of perennial grasses (Lucerne - initial blossom - BBCH 60, gramineous plants - initial blossom - BBCH 49-51). Results. Influence of fertilizer system and presowing treatment of seeds of leguminous component on fodder productivity of Lucerne-cereal grass mixture is determined. Conclusions. In conditions of natural humidification of Western Forest-steppe on dark grey average loamy soils use of presowing treatment of seeds of leguminous component, entering phosphoric-potash fertilizers in dose of P60K60 and foliar top dressing with Triamin Plus in dose of 2 l/hectare in the beginning of formation of each hay cutting provide the greatest productivity of Lucerne-cereal grass mixture $-10,41 \mathrm{t} /$ hectare of dry matter, 7,97 t/hectare f.u., 101,2 Gjoule/hectare of exchange energy and 1,24 t/hectare of digested protein.
\end{abstract}

Keywords: leguminous-grass mixtures, dry matter, feed units, exchange energy, digested protein.

https://doi.org/10.31073/agrovisnyk201902-04

Introduction. Sustainable development of the country's agriculture is impossible without the revival of efficient animal husbandry, as one of the components of food security of the state. It is already known that Ukraine is considerably inferior to developed countries and imports significant volumes of meat and milk [11, 13].

A prerequisite for the efficient development of livestock is to increase the level of supply of its highquality, balanced feed forage [5]. One way to address this issue is to grow perennial legumes and their mixtures [15]. Long-term legume grasses play an important role in increasing production and improving the quality of feed, as reflected in the Strategic Guidelines for Agricultural Development of Ukraine for the period up to 2020 and the Concept for the Development of Fodder Production in Ukraine until 2025 [11, 13] .

The urgency of the problem of producing a sufficient amount of feed with high quality indicators has become aggravated in recent decades, due to climatic changes occurring on a planetary scale and reflected in the territory of Ukraine.

In this regard, when selecting components for the creation of high-yielding grasslands, along with their high fodder qualities, attention must be paid to the drought-tolerance of selected species, which will enable to some extent neutralize the negative effects of adverse weather conditions [6].

One of the long-standing legume grasses that best meets the given parameters is alfalfa, which in the beginning of the third millennium is the most common world-long, long-legume culture. Deep penetration of the root system (more than $6 \mathrm{~m}$ ) allows it to absorb moisture from the lower layers of the soil, which has a positive effect on drought tolerance [16]. 
Analysis of recent research and publications. An important feature of alfalfa seedlings is that it can be grown both in single-seeded crops and in cereal crops. It prolongs the productive longevity of sown meadow agrophytocenoses and exceeds single-crop crops by the level and stability of crops, the balance of nutrients, the degree of influence on soil fertility. At the same time, the cost of feed production is significantly reduced and the energy efficiency ratio increases [14].

In this connection, the issues of development of new and improvement of existing technological methods of increasing the productivity of seeded bean-cereal agrophytocenoses are relevant. According to literary scientific sources, the most significant and universal measure to increase the productivity of perennial meadow grass is fertilizer. In addition, in conditions of growing dryness of the growing season, biostimulants, antistressens, become an integral part of intensive technologies. With their help, they solve issues that can not be realized by traditional methods and methods [7]. This is confirmed by the data of many scientific studies conducted in various agro-climatic zones of Ukraine [1-2, 4, 8-10]

An integral technological process of cultivating alfalfa seedlings in single-breeding and compatible crops is pre-seed treatment of seed with bacteria of the genus Rhizobium, which contributes to the improvement of the process of symbiotic nitrogen fixation [16]

However, despite the large number of studies on the use of fertilizers and growth stimulants in the technologies of creating and using sowing bean-cereal agrophytocenoses, many aspects of this problem are still underdeveloped due to the emergence of new varieties of perennial bean and cereal grasses and their response to factors life in conditions of climate change.

The purpose of research. To investigate the effect of pre-seed treatment of seed of bean component and fertilizer system on feed productivity of alfalfa-cereal grass mix

Materials and methods. The research was carried out by the laboratory of fodder production and agroecology of the Ternopil experimental station of the Institute of veterinary medicine on dark gray podzolized soils with a medium loamy granulometric composition.

The scheme of the experiment included three factors (Table 1).

Table 1. Scheme of experiment

\begin{tabular}{|c|c|c|}
\hline Factor A - seed treatment & $\begin{array}{c}\text { Factor B - doses of mineral } \\
\text { fertilizers }\end{array}$ & Factor C - Foliar nutrition \\
\hline $\begin{array}{l}\text { 1. Without processing; } \\
\text { 2. Seed treatment with growth } \\
\text { stimulator Viva; } \\
\text { 3. Seed treatment with Risbofite; } \\
\text { 4. Seed treatment with growth } \\
\text { stimulator Viva and Risbofit }\end{array}$ & $\begin{array}{l}\text { 1. Without fertilizer. } \\
\text { 2. } \mathrm{P}_{60} \mathrm{~K}_{60} \text {. }\end{array}$ & $\begin{array}{l}\text { 1. Without feeding; } \\
\text { 2. With supplementation with } \\
\text { Trimin Plus it is normal } 2.0 \text { I/ ha }\end{array}$ \\
\hline
\end{tabular}

The herb mix consisted of Lucerne seedlings (Medicago sativa L.) of the Sinuchus variety, the stomachoglass of the Bromus inermis Leus., The fistulae of the Ludmilla straw (Festuca arundinaceae Schreb.) And was formed in the light of the research results of the Institute of Forage and Rural Podillya NAAS [ 3].

Indigenous nutrition by Triamine Plus was carried out at the beginning of the regrowth of each slope (BBCH 31 for alfalfa and $\mathrm{BBCH} 21-22$ for cereal herbs) in the presence of a sufficient leaf surface at a rate of $2.0 \mathrm{I} / \mathrm{ha}$ and a working solution of $250 \mathrm{I} / \mathrm{ha}$.

Mowing of grass mixed with the onset of oblique maturation of perennial grasses (alfalfa sowing-the beginning of flowering - $\mathrm{BBCH} 60$, cereals - at the beginning of flowering - $\mathrm{BBCH} 49-51$ ).

Weather conditions during the research years (2014-2016) differed from the average long-term indicators, which made it possible to estimate the influence of the investigated factors under different climatic conditions. So, in 2014, in the period since the beginning of the restoration of the vegetation - before the last slump fell out 
$353 \mathrm{~mm}$ of precipitation, in $2015-242 \mathrm{~mm}$, and in $2016-455 \mathrm{~mm}$, while the average multi-year indicator is $452 \mathrm{~mm}$. The average air temperature during the above-mentioned period was $+13.7^{\circ} \mathrm{C}$ in $2014,15.0^{\circ} \mathrm{C}$ in 2015 and $17.5^{\circ} \mathrm{C}$ in 2016 , with an average annual value of $+12.6^{\circ} \mathrm{C}$.

Sizes of sites $-25 \mathrm{~m}^{2}$ repetition in the experiment - four-time.

Studies are conducted in accordance with generally accepted methods for scientific research on fodder production and onions [12]. Generalization of materials for the use of generally accepted methods and calculations of research results was carried out using the software STATISTICA and Agrostat.

Results. The study of the influence of inoculation, doses of mineral fertilizers and fecal crops on the formation of fodder productivity of alfalfa and cereal grass showed high efficiency of the above mentioned technological methods of cultivation, (Table 2).

The yield of dry matter in the sum of three slopes of bean-cereal agrophytocenose was 5.24-10.41 $t$ / ha, depending on the variant of the experiment. The option without pre-seed treatment, without fertilizers and without extra-root crops, provided dry matter yields only at $5.24 \mathrm{t} / \mathrm{ha}$, which is significantly lower compared to the investigated variants.

Table 2. Fodder productivity of alfalfa-cereal agrophytocenoses depending on the elements of technology (average 2014-2016).

\begin{tabular}{|c|c|c|c|c|c|c|c|}
\hline \multirow[b]{2}{*}{$\begin{array}{l}\text { Treatment of } \\
\text { alfalfa seeds }\end{array}$} & \multirow[b]{2}{*}{$\begin{array}{l}\text { Doses of } \\
\text { mineral } \\
\text { fertilizers }\end{array}$} & \multirow[b]{2}{*}{ Foliar nutrition } & \multicolumn{4}{|c|}{ Yield per 1 ha of } & \multirow{2}{*}{ 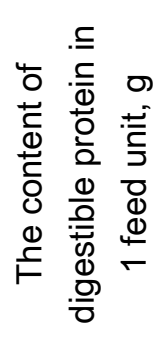 } \\
\hline & & & 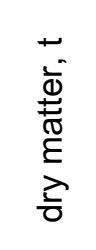 & $\begin{array}{l}+ \\
\frac{0}{0} \\
\stackrel{0}{5} \\
5 \\
\overline{0} \\
\frac{0}{0} \\
\frac{0}{0}\end{array}$ & 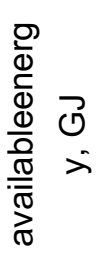 & 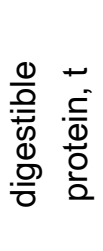 & \\
\hline \multirow{2}{*}{$\begin{array}{l}\text { Without } \\
\text { processing }\end{array}$} & $\begin{array}{l}\text { Without } \\
\text { fertilizer }\end{array}$ & \multirow{8}{*}{ Without feeding } & 5,24 & 3,11 & 45,7 & 0,44 & 136,9 \\
\hline & $\mathrm{P}_{60} \mathrm{~K}_{60}$ & & 7,51 & 4,79 & 66,6 & 0,67 & 140,2 \\
\hline \multirow{2}{*}{$\begin{array}{l}\text { Seed treatment } \\
\text { with growth } \\
\text { stimulator Viv }\end{array}$} & $\begin{array}{l}\text { Without } \\
\text { fertilizer }\end{array}$ & & 5,83 & 3,88 & 54,4 & 0,54 & 140,0 \\
\hline & $\mathrm{P}_{60} \mathrm{~K}_{60}$ & & 8,06 & 5,56 & 75,5 & 0,81 & 149,5 \\
\hline \multirow{2}{*}{$\begin{array}{l}\text { Seed treatment } \\
\text { with Risbofite }\end{array}$} & $\begin{array}{l}\text { Without } \\
\text { fertilizer }\end{array}$ & & 6,41 & 3,73 & 51,8 & 0,52 & 139,3 \\
\hline & $\mathrm{P}_{60} \mathrm{~K}_{60}$ & & 8,39 & 5,65 & 75,0 & 0,84 & 143,6 \\
\hline \multirow{2}{*}{$\begin{array}{l}\text { Seed treatment } \\
\text { with growth } \\
\text { stimulator Viva } \\
\text { and Risbofit }\end{array}$} & $\begin{array}{l}\text { Without } \\
\text { fertilizer }\end{array}$ & & 7,43 & 4,55 & 62,8 & 0,64 & 143,8 \\
\hline & $\mathrm{P}_{60} \mathrm{~K}_{60}$ & & 9,09 & 6,65 & 87,0 & 1,01 & 153,9 \\
\hline \multirow{2}{*}{$\begin{array}{l}\text { Without } \\
\text { processing }\end{array}$} & $\begin{array}{l}\text { Without } \\
\text { fertilizer }\end{array}$ & \multirow{6}{*}{$\begin{array}{c}\text { With } \\
\text { supplementation } \\
\text { with Trimin Plus it is } \\
\text { normal }\end{array}$} & 6,18 & 4,05 & 56,6 & 0,56 & 138,3 \\
\hline & $\mathrm{P}_{60} \mathrm{~K}_{60}$ & & 8,31 & 5,53 & 75,7 & 0,79 & 145,2 \\
\hline \multirow{2}{*}{$\begin{array}{l}\text { Seed treatment } \\
\text { with growth } \\
\text { stimulator Viv }\end{array}$} & $\begin{array}{l}\text { Without } \\
\text { fertilizer }\end{array}$ & & 7,02 & 4,73 & 65,9 & 0,66 & 141,2 \\
\hline & $\mathrm{P}_{60} \mathrm{~K}_{60}$ & & 9,22 & 6,61 & 88,1 & 0,98 & 151,4 \\
\hline \multirow{2}{*}{$\begin{array}{l}\text { Seed treatment } \\
\text { with Risbofite }\end{array}$} & $\begin{array}{l}\text { Without } \\
\text { fertilizer }\end{array}$ & & 7,43 & 4,93 & 67,2 & 0,71 & 139,9 \\
\hline & $\mathrm{P}_{60} \mathrm{~K}_{60}$ & & 9,50 & 6,71 & 86,7 & 1,03 & 148,8 \\
\hline
\end{tabular}




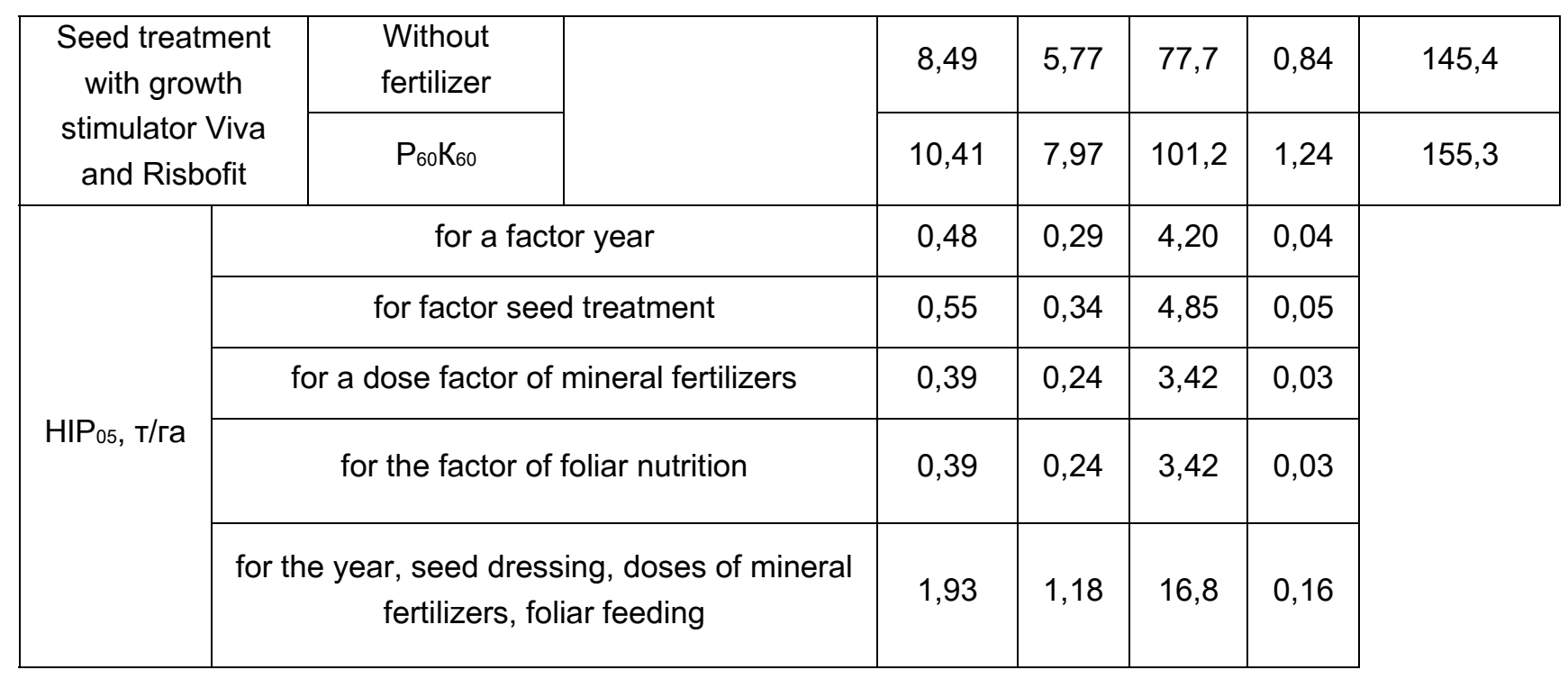

Application in the technology of creating and using sowing hay seeds for pre-sowing seed treatment, introducing phosphorus-potassium fertilizers and foliar nutrition contributed to the better development of the root system, the activity of the bean-rhizobial complex and the photosynthetic leaf surface, which ensured the growth of the productivity of alfalfa-cereal grass mix.

Treatment of seeds of alfalfa seeded growth stimulator Viva provided a dry matter yield of $5.83 \mathrm{t} / \mathrm{ha}$, Risobophyta $-6.41 \mathrm{t} / \mathrm{ha}$, and their combination $-7.43 \mathrm{t} / \mathrm{ha}$, which is more by $0.59-2.19 \mathrm{t} /$ ha of dry matter when compared with the control.

The use of phosphorus-potassium fertilizer in a dose of P60K60 contributed to the growth of grass seed yield to 7.51-9.09 $\mathrm{t} /$ ha of dry matter, depending on the variation of the experiment.

Indigenous nutrition Triamine Plus has positively affected the dry matter outlet per hectare, both in self-application and in combination with phosphoric-potassium fertilizer in a dose of $\mathrm{P}_{60} \mathrm{~K}_{60}$. The productivity of one hectare at the output of dry matter was 6.18-10.41 tons.

In general, among the experimental variants, on average, over the years of research, the highest dry matter performance was marked by the option of sowing treated with the growth stimulator Viva and the inoculant Risbofit seed of alfalfa seed, as well as the introduction of phosphoric potassium fertilizer $\mathrm{P}_{60} \mathrm{~K}_{60}$ and the introduction of foliar fertilization Triamine Plus - $10.41 \mathrm{t} / \mathrm{ha}$.

On the basis of the dispersion analysis of the obtained data, it was found that the level of the formed crop of alfalfa-cereal grass mixture $47.55 \%$ depended on the doses of mineral fertilizers, $25.68 \%$ of the preseed processing of seeds of the bean component, $13.53 \%$ of foliar feeding and $9.57 \%$ Hydrothermal conditions of the growing season of research years, (Fig. 1).

The insignificant influence of the hydrothermal conditions of the growing season on the formation of the crop of alfalfa-cereal grass mix is associated with the biological characteristics of its components, which are characterized by high drought tolerance. This allowed to obtain a high yield of dry matter in the face of a lack of moisture. 


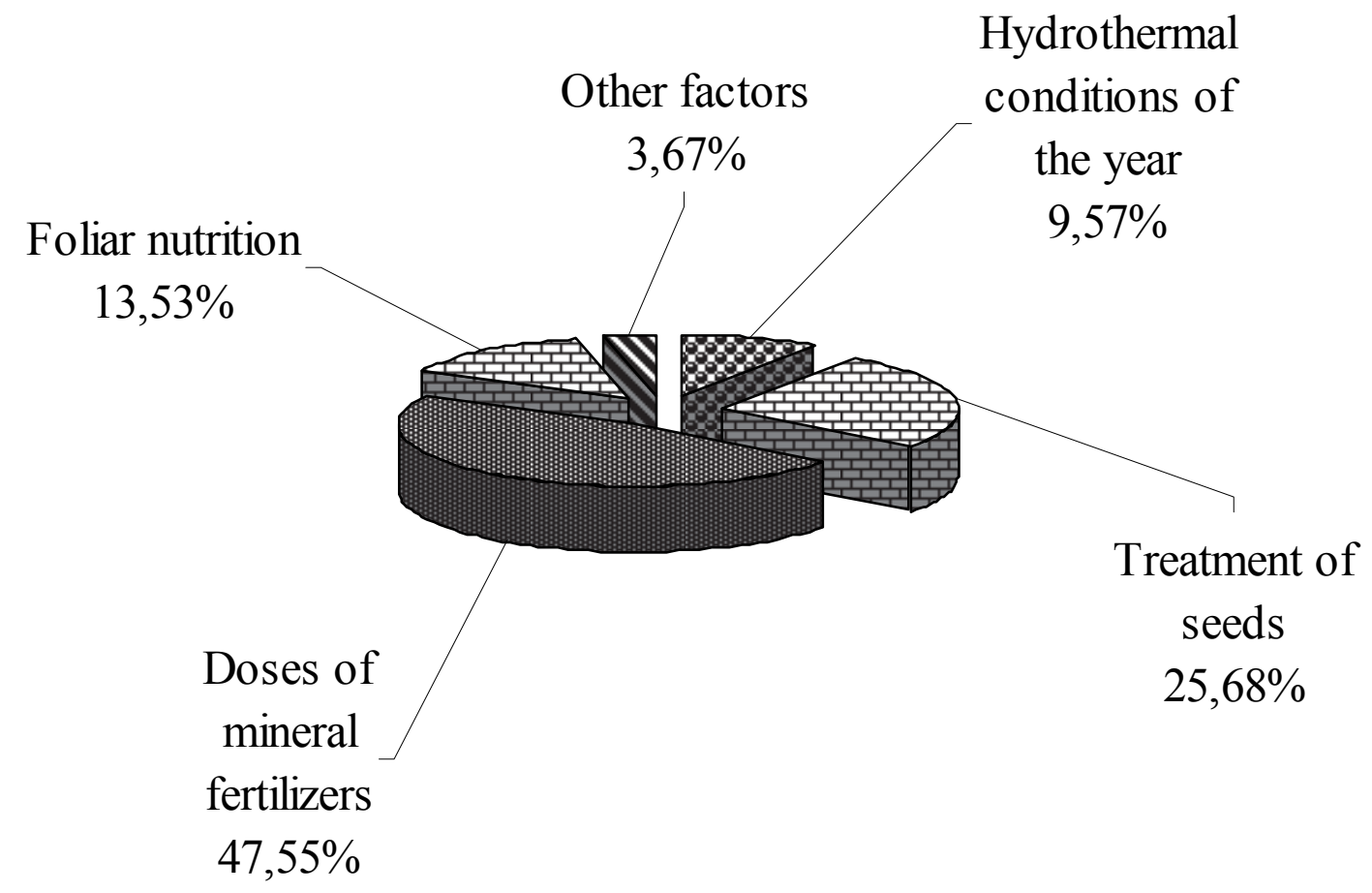

Fig. 1. The share of influence of factors in the formation of the crop of lucerne-cereal grass mix, average for 2014-2016.

The calculations of fodder productivity of one hectare of alfalfa and cereal grass mix confirm the high efficiency and expediency of intensification measures for meadow fodder production. Due to the increase in the yield of dry matter and the nutritional value of feed, the yield of feed units was 3.11-7.97 $\mathrm{t} / \mathrm{ha}$, and the exchange energy - 45.7-101.2 GJ / ha, depending on the variant of the experiment/

The lowest performance was marked by a control variant, which did not use inoculation, fertilization and endocrine nutrition -

$3,11 \mathrm{t} /$ ha of feed units, $45,7 \mathrm{GJ} /$ ha of exchange energy and $0,44 \mathrm{t} /$ ha of digestible protein. Provision of 1 fodder unit with digestible protein was $136.9 \mathrm{~g}$.

Conducting the pre-seed treatment of the bean component by the growth stimulator Viva provided a yield of one-hectare of 3.88-5.56 tons of feed units, 54.4-75.5 GJ of exchange energy and 0.54-0.81 $\mathrm{t} / \mathrm{ha}$ of digestible protein in variants without applying extra-root infusions and 4.73-6.61 tons of feed units, 65.9-88.1 GJ of exchange energy and

0,66-0,98 $\mathrm{t} /$ hectare of digestible protein when spraying crops with Triamine Plus. The provision of 1 $\mathrm{kDa}$ of digestible protein was $140.0-149.5 \mathrm{~g}$ and $141.2-151.4 \mathrm{~g}$ respectively

Use in technologies of sowing meadow agrophytocenoses of inoculant Risobofit contributed to the growth of fodder productivity per hectare of crops to 3.73-5.65 tons of feed units, 51.8-75.0 GJ of exchange energy of $0.52-0.84$ tons of digestible protein. Additional application of vegetative plants Triamina Plus increased feed output to $4.93-6.71 \mathrm{t} / \mathrm{ha}$, exchange energy - up to 67.2-86.7 GJ / ha, digestible protein - to 0.71-1.03 t/Ha.

Application for pre-sowing treatment of seed of growth stimulator Viva and inoculant. Risobophyte, thanks to the synergistic action of drugs, provided the highest productivity of alfalfa-cereal grass mix. Thus, feed units, depending on the doses of mineral fertilizers and fodder feeding, were 4.55-7.97 $\mathrm{t} / \mathrm{ha}$, the exchange energy - 62.8-101.2 GJ / ha, the digestible protein - 0.64-1.24 t/ Ha. The provision of 1 feed unit with digestible protein was $143.8-153.9 \mathrm{~g}$ and $145.4-155.3$ respectively

Among the experimental variants, the highest indices of fodder productivity were noted in the variant where the pre-sowing treatment of alfalfa seeds with growth stimulator Viva and inoculant Risbofit were 
carried out, phosphoric-potassium fertilizers P60K60 superficial and Triamin Plus extracorporeal $-7.97 \mathrm{t} /$ ha of feed units and 101.2 GJ / ha of exchange energy, $1.24 \mathrm{t} /$ ha of digestible protein.

\section{Discussion}

In the conditions of natural humidification of the western forest-steppe, on dark gray medium slush soils, the use of pre-sowing processing of the seeds of the bean component, the application of phosphoricpotassium fertilizers in the normal range of $\mathrm{P} 60 \mathrm{~K} 60$ and foliar fertilization with Trimamin Plus in the normal range of $2.0 \mathrm{I} / \mathrm{ha}$ at the beginning of the formation of each slope provided the highest yield of alfalfa -crack grass mix. The estimated yield of dry matter was $10.41 \mathrm{t} / \mathrm{ha}$, fodder units $7.97 \mathrm{t} / \mathrm{ha}$, exchange energy 101.2 GJ / ha and digestible protein $1.24 \mathrm{t} / \mathrm{ha}$. Provision of $1 \mathrm{k} .0 \mathrm{~d}$. the digestible protein at that was $155.3 \mathrm{~g}$.

Due to the inclusion in the grass mix of drought-resistant species of perennial legumes - alfalfa (Medicago sativa L.) and cereals (Festuca arundinaceae Schreb.) And sturgeon (Bromus inermis Leus.) Largely leveled the influence of the hydrothermal conditions of the growing season, the proportion of exposure on the formation of the crop was $9.57 \%$.

\section{References}

1. Bakhmat M.I., Stepanchenko V.M. (2015) Produktyvnist bahatorichnykh travosumishok zalezhno vid vplyvu biopreparativ i udobrennia [Productivity of multi-year grass mixtures depending on the influence of biologics and fertilizers]. Feed and feed production, 80, 25-28.

2. Buhryn L. M. Buhryn O.M. (2013) Kormova produktyvnist pasovyshchnykh ahrotsenoziv zalezhno vid udobrennia ta zastosuvannia biopreparativ [Feed productivity of pasture agrocenoses depending on fertilization and application of biological products]. Foothills and mountain farming and animal husbandry, 55 (II), 20-27. [in Ukraine].

4. Veklenko Yu.A., Kovtun K. P., Bezvuhliak L. I. (2017) Vplyv sposobiv sivby i prostorovoho rozmishchennia komponentiv na produktyvnist liutserno-zlakovykh ahrofitotsenoziv $v$ umovakh Lisostepu Pravoberezhnoho [Influence of sowing methods and spatial arrangement of components on the productivity of alfalfa and cereal agrophytocenoses in the conditions of the Forest-steppe of the Right Bank]. Feed and feed production, 83, 120-126. [in Ukraine].

5. Vyshnevska O.V. Didkivskyi S.Yu., Tuhuieva I.V., Veiko L.I. (2015) Formuvannia rostovykh protsesiv i produktyvnosti bobovo-zlakovykh travosumishok zalezhno vid systemy udobrennia ta sposobiv sivby [Formation of growth processes and productivity of bean-cereal grass mixtures depending on fertilizer system and sowing methods]. Agro-industrial production of Polissya, 8, 36-41. [in Ukraine].

6. Hrabchuk I.F. (2013) Otsinka efektyvnosti kormovyrobnytstva ta napriamy yii zrostannia [Estimation of efficiency of fodder production and directions of its growth]. Collection of scientific works of Vinnytsia National Agrarian University. Series: Economic Sciences, 4 (81), 72-81. [in Ukraine].

7. Hratylo O.D., Petrychuk L. I., Smienova H. S. (2017). Modeli ahrofitotsenoziv pasovyshchnosinokisnoho vykorystannia dlia polipshennia vyrodzhenykh pryrodnykh kormovykh uhid na pivdni Ukrainy [Models of agrophytocenoses of pasture and hayland use for the improvement of degenerate natural forage farms in the south of Ukraine]. Sheep and goat breedin, 2, 223-241. [in Ukraine].

8. Dehodiuk E.H. (2015). Antystresanty Roslyn [Plant anti-stresses]. The Ukrainian Fermer, №5, 50-51. [in Ukraine].

9. Demydas H.I., Demtsiura Yu.V. (2011) Kormova produktyvnist bobovo-zlakovykh travosumishok zalezhno vid vydovoho skladu ta sposobu stvorennia travostoiu [Fodder productivity of bean-cereal grass mixtures depending on species composition and method of creation of grass]. Collection of scientific works of Vinnytsia National Agrarian University. Fodder production., 9 (49), 95-101. [in Ukraine].

10. Kovtun K. P. Veklenko Yu.A., Kopaihorodskyi V.M., Bezvuhliak L.I., Onyshchenko M.A. (2013) Formuvannia produktyvnosti liutserny posivnoi pry riznykh sposobakh udobrennia ta inokuliatsii $v$ umovakh Lisostepu pravoberezhnoho [Formation of productivity of alfalfa seeding at different methods of fertilization and inoculation in the conditions of the forest-steppe of right-bank]. Feed and feed production, 76, 188-194. [in Ukraine]. 
10. Kotiash U. O., Panakhyd H.Ya., Yarmoliuk M.T. (2013) Formuvannia sinokisnoho travos- toiu zalezhno vid tryvaloho vnesennia mineralnoho dobryva [Formation of hayfield grass depending on the prolonged application of mineral fertilizers]. Feed and feed production, 76, 158-162. [in Ukraine].

11. Lupenko Yu.O. Mesel-Veseliak V.Ya. (2012) Stratehichni napriamy rozvytku silskoho hospodarstva Ukrainy na period do 2020 roku [Strategic directions of development of agriculture of Ukraine for the period till 2020], National Science Center Institute of Agrarian Economics, 182. [in Ukraine].

12. Babych A. O. ed (1998) Metodyka provedennia doslidiv z kormovyrobnytstva i hodivli tvaryn [Method of conducting experiments on feed production and feeding animals], Ahrarna nauka, 77. [in Ukraine].

13. Petrychenko V.F., Korniichuk O.V. (2012) Stratehiia rozvytku kormovyrobnytstva v Ukraini [Strategy of development of feed production in Ukraine]. Feed and feed production, 73. 3-10. [in Ukraine].

14. Prorochenko S. (2016) Liutsernovo-zlakovi travosumishky vazhlyvyi chynnyk u formuvanni kormovoi bazy [Alfa-alfa grass mix is an important factor in the formation of the forage base] Innovative technologies and intensification of development of national production: Materials III International. science-practice conf. Ternopil, 1. 96-97. [in Ukraine].

15. Semenda O.V. (2011) Formuvannia stiikoi kormovoi bazy yak elementa intensyfikatsii molochnoho skotarstva [Formation of a stable feed base as an element of intensification of dairy cattle breeding]. Economics and Management of the Agro-Industrial Complex: Collection sciences works, 6 (89), 153-156. [in Ukraine].

16. Dan Undersander et. al. (2010) Alfalfa Management Guide. Printed in the U.S.A., 68 p. 